\title{
CULTURE CRASH
}


Yale UNIVERSITY PRESS I NEW HAVEN AND LONDON 


\title{
CULTURE
}

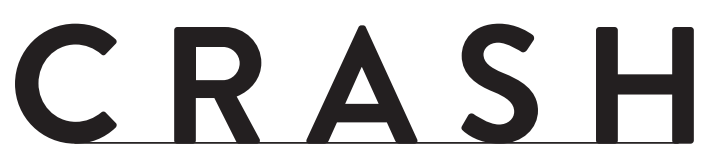

\author{
THE \\ KILLING \\ OF THE \\ CREATIVE \\ CLASS \\ SCOTT TIMBERG
}


Copyright (C) 2015 by Scott Timberg. All rights reserved. This book may not be reproduced, in whole or in part, including illustrations, in any form (beyond that copying permitted by Sections IO7 and Io8 of the U.S.

Copyright Law and except by reviewers for the public press), without written permission from the publishers.

Yale University Press books may be purchased in quantity for educational, business, or promotional use. For information, please e-mail sales.press@yale.edu (U.S. office) or sales@yaleup.co.uk (U.K. office).

Printed in the United States of America.

Library of Congress Cataloging-in-Publication Data

Timberg, Scott.

Culture crash : the killing of the creative class / Scott Timberg. pages $\mathrm{cm}$

Includes bibliographical references and index. ISBN 978-0-300-I9588-o (hardback)

I. Creative ability-United States-History-2 Ist century. 2. Social classes-United States-History-2ist century. 3. Social change-United

States-History-2 Ist century. 4. Popular culture-United StatesHistory-2 Ist century. I. Title.

$$
\begin{gathered}
\mathrm{BF}_{408 . \mathrm{T}_{55}} 2 \mathrm{OI} 5 \\
305 \cdot 5^{\prime} 50973-\mathrm{dc2} 3 \quad 2014015252
\end{gathered}
$$

A catalogue record for this book is available from the British Library.

This paper meets the requirements of ANSI/NISO Z39.48-I992 (Permanence of Paper).

IO $98 \begin{array}{llllllll} & 7 & 6 & 5 & 4 & 32 & 2\end{array}$ 
To Sara, for helping us survive

this wave of creative destruction; and to Ian, who may live to see

how the story ends 
This page intentionally left blank 
The present is only faced, in any generation, by the artist. ... The absolute indispensability of the artist is that he alone, in the encounter with the present, can give the pattern recognition. He alone has the sensory awareness to tell us what our world is made of. He is more important than the scientist.

-Marshall McLuhan, I968

He won't hear the thing come in. It travels faster than the speed of sound. The first news you get of it is the blast. Then, if you're still around, you hear the sound of it coming in.

-Thomas Pynchon, Gravity's Rainbow 
This page intentionally left blank 